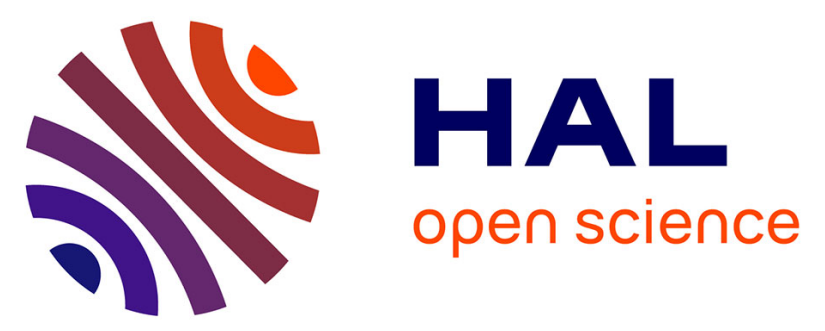

\title{
The Principles of Campus Conception: A Spatial and Organizational Genealogy. What knowledge Can We Use from a Historical Study in Order to Analyse the Design Processes of a New Campus?
}

Caroline Scotto

\section{To cite this version:}

Caroline Scotto. The Principles of Campus Conception: A Spatial and Organizational Genealogy.What knowledge Can We Use from a Historical Study in Order to Analyse the Design Processes of a New Campus?. Materiality and Time. Historical Perspectives on Organizations, Artefacts and Practices, 2014, 978-1-137-43210-0. hal-01082181

HAL Id: hal-01082181

https: / hal-mines-paristech.archives-ouvertes.fr/hal-01082181

Submitted on 12 Nov 2014

HAL is a multi-disciplinary open access archive for the deposit and dissemination of scientific research documents, whether they are published or not. The documents may come from teaching and research institutions in France or abroad, or from public or private research centers.
L'archive ouverte pluridisciplinaire HAL, est destinée au dépôt et à la diffusion de documents scientifiques de niveau recherche, publiés ou non, émanant des établissements d'enseignement et de recherche français ou étrangers, des laboratoires publics ou privés. 
THE OUTSOURCING ENTERPRISE

From Cost Management to Collaborative Innovation

Leslie P. Willcocks, Sara Cullen and Andrew Craig

COLLABORATION IN OUTSOURCING

A Journey to Quality

Sjaak Brinkkemper and Slinger Jansen

SUSTAINABLE GLOBAL OUTSOURCING

Ron Babin and Brian Nicholson

\section{Materiality and Time}

Historical Perspectives on Organizations, Artefacts, and Practices

Edited by

Francois-Xavier de Vaujany

Université Paris-Dauphine, France

Nathalie Mitev

London School of Economics, UK

Pierre Laniray

Université Paris-Dauphine, France

and

Emmanuelle Vaast McGill University, Canada

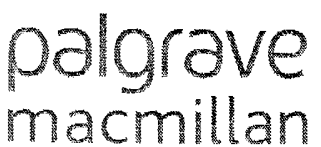


Selection and editorial content @ Francois-Xavier de Vaujany, Nathalie Mitev Pierre Laniray, and Emmanuelle Vaast 2014

Individual chapters $\odot$ Contributors 2014

All rights reserved. No reproduction, copy or transmission of this

publication may be made without written permission.

No portion of this publication may be reproduced, copied or transmitted save with written permission or in accordance with the provisions of the Copyright, Designs and Patents Act 1988, or under the terms of any licence permitting limited copying issued by the Copyright Licensing Agency, Saffron House, 6-10 Kirby Street, London EC 1N 8TS.

Any person who does any unauthorized act in relation to this publication may be liable to criminal prosecution and civil claims for damages.

The authors have asserted their rights to be identified as the authors of this work in accordance with the Copyright, Designs and Patents Act 1988.

First published 2014 by

PALGRAVE MACMILLAN

Palgrave Macmillan in the UK is an imprint of Macmillan Publishers Limited, registered in England, company number 785998, of Houndmills, Basingstoke Hampshire RG21 6XS

Palgrave Macmillan in the US is a division of St Martin's Press LLC

175 Fifth Avenue, New York, NY 10010.

Palgrave Macmillan is the global academic imprint of the above companies and has companies and representatives throughout the world.

Palgrave ${ }^{\circledR}$ and Macmillan ${ }^{\circledR}$ are registered trademarks in the United States, the United Kingdom, Europe and other countries

ISBN: 978-1-137-43210-0

This book is printed on paper suitable for recycling and made from fully managed and sustained forest sources. Logging, pulping and manufacturing processes are expected to conform to the environmental regulations of the country of origin.

A catalogue record for this book is available from the British Library.

Library of Congress Cataloging-in-Publication Data

Vaujany, Francois-Xavier de.

Materiality and time : historical perspectives on organizations, artefacts

and practices / Francois-Xavier de Vaujany, Université Paris-Dauphine, France

Nathaie Mitev, London School of Economics, UK, Pierre Laniray, Université

Paris Dauphin, Fronce, Emmanuelle Vast, McCill University, Canada.

pages $\mathrm{cm}$.-(Technology, work and globalization)

pages cm.- (Technology,

1. Organization - History. 2. Organizational change. 3. Information technology - Management I. Title.

HD30.5.V38 2014

$302.3^{\prime} 509-d c 23$

201402208

\section{Contents}

List of Illustrations

Notes on Contributors

Introduction: Time and Materiality: What Is at Stake in the Materialization of Time and Time as a Materialization?

Francois-Xavier de Vaujany, Nathalie Mitev, Pierre Laniray, and Emmanuelle Vaast

Part I Materializing Time and History in Organizations: What Is at Stake?

1 Time, History, and Materiality JoAnne Yates

2 Dual Iconographies and Legitimation Practices in Contemporary Organizations: A Tale of the Former NATO Command Room François-Xavier de Vaujany and Emmanuelle Vaast

3 Evolution of Non-Technical Standards: The Case of Fair Trade Nadine Arnold

Part II Temporal Dynamics of Artefacts and Materiality in Organizations: The Importance of Material Traces

4 Making Organizational Facts, Standards, and Routines: Tracing Materialities and Materializing Traces Christine McLean and Jeremy Aroles

5 Management Control Artefacts: An Enabling or Constraining Tool for Action? Questioning the Definition and Uses of the Concept of Affordances from a Management Control Perspective Émilie Bérard (transl. Andrew Beresford)

6 Clocks, Clerks, Customers: Queue Management Systems, Post-Socialist Sensibilities, and Performance Measurement at a Retail Bank

Zsuzsanna Vargha 
7 When the Omerta is Broken: Sociomateriality and the History of Hazing in French Universities

Hélène Lambrix

\section{Part III Stretching Out Time and Materiality in} Organizations: From Presentism to Longue Durée

The Historian's Present

François Hartog

9 The Role of History in Information Systems Research: Beyond Presentism Nathalie Mitev

10 The Principles of Campus Conception: A Spatial and Organizational Genealogy. What Knowledge Can We Use from a Historical Study in Order to Analyse the Design Processes of a New Campus? Caroline Scotto

Conclusion: Understanding Materiality and the Material Underpinnings of Organizations through a Longue Durée Approach Nathalie Mitev, François-Xavier de Vaujany, Emmanuelle Vaast, and Pierre Laniray

Epilogue: Strategic Coordination Information Technologies and Europe-USA's Organizations. Time-and-History Regimes and Information Technologies in Refolding Long-Term Elective Affinities Peter Clark

\section{List of Illustrations}

\section{Figures}

I.1 Logical structure of the book

2.1 Views of the Raymond Aron (RA) room from 1959 to today

4.1 Plan/Do/Check/Adjust illustration

4.2 Ink density graphs

6.1 Call-number dispenser machine showing transaction types and number of customers waiting for each

6.2 Electronic call-number display screen hung in the customer space of the branch, showing clerk number and customer call number

6.3 Bank clerk's queue management screen

6.4 Branch manager's screen showing queue status and other activity information for each clerk

' Stakeholders' behaviours during crisis timeline

10.2 Illustrates the consistency between organizational design principle and spatial design principle

\section{Tables}

2.1 Three symbolic places

2.2 Dual iconographies, entanglement of information and artefacts, and legitimation practises

A.1 Sample of events

A.2.2 Key visual artefacts pointed out in the flow of communication practises and their relationships with symbolic spaces

3.1 Current Fair Trade standard world

3.2 Textual artefacts demanded from producers by the Fair Trade coffee standards

4.1 Ink density table

7.1 Reputation damages and the broader notion in the literature review

7.2 Important dates in hazing history in France

7.3 Number of online press comments before and after the event

10.1 Differences of the concept of campus

10.2 The components of the French campus example in the $1960 \mathrm{~s}$ and the current Campus Paris-Saclay project 
The Principles of Campus Conception: A Spatial and Organizational Genealogy. What Knowledge Can We Use from a Historical Study in Order to Analyse the Design Processes of a New Campus?

Caroline Scotto

\section{Introduction}

The spatial issue has traditionally played a role in organizational and management studies (Clegg \& Kornberger, 2006). This chapter contributes to the recent growing interest of scholars in the relationship between spatial structure and organizational practices through the idea of "organizational space" (Hernes, 2004; Taylor \& Spicer, 2007; Elsbach \& Pratt, 2007; Van Marrewijk \& Yanow, 2010; de Vaujany \& Vaast, 2013).

Researchers mainly analyse this relationship ex post, through built-up spaces. Very few empirical studies focus on the design phase. The study of design processes - organizational and spatial - raises methodological challenges and investigates how the relationship between these processes could be analysed.

The literature provides two examples of ways to approach this question. On the one hand, Yoo et al. (2006) investigate the practices of a major architectural agency as a way to analyse the relationship between organizational and spatial design processes. Through the designers' "design gestalt" composed of "architectural vision, tight coupling of technologies and collaborative design network" (Yoo et al., 2006, 221) which implies client collaboration this study sheds light on how the client and his or her organization affect design processes. According to the authors, "designing products and designing organizations cannot be and should not be separated" (Yoo et al., 2006, 228). On the other hand, Marianne Stang Vaaland proposes to investigate end-user participation as a way to study the potential link between the two processes. In her thesis, What we talk about when we talk about space: End User Participation between Processes of Organizational and Architectural Design (2010), the author starts her research on the assumption that "traditionally, managers do not approach the organizational design process from a spatial perspective" and that they focus on practices through work processes, collaboration and production. "Similarly, architects (and also other main players involved in the building process: contractors, engineers and more) are not trained in issues that regard organizational design." For Vaaland, the attention of space designers is focused on functional, esthetical, and technical issues. (Vaaland, 2010, 10). According to the author, the organizational design and spatial design processes are traditionally separate.

The first study calls for an interaction between organizational and spatial design processes, and the second claims that these two processes are traditionally separated. I propose to explore the hypothesis that a historical approach to these two processes could reveal the nature of this relationship through time. In order to do so, this contribution focuses on the university campus. This object gives a priori the adequate characteristics because of the organizational aspect of higher educational institutions and a spatial aspect because of being the physical host of these institutions.

In order to discuss the nature of the relationship between both designs: organizational and spatial, this contribution is based on three years of research on the conception processes of the Campus Paris-Saclay (France) project that started in 2008 . This project is part of the implementation of a nationwide public policy regarding France's higher education and research system. Its main purpose is to give France a system of excellence in order to gain international visibility and competitiveness. The specificity of the Saclay project mainly lies on the long history of the Saclay territory. The analysis of the Saclay territory's history starting with 1946 shows that there has been a succession of establishments of higher education and research institutions through real estate projects, disparate territorial projects, and several scientific cooperation attempts (Duby, 1999). Since 2008, the campus, as a physical and organizational object, appears to be the solution of France's strategy to converge these three elements. Hence, I use the design of a new campus as a "laboratory" in order to analyse the relationship between organizational and spatial design processes at two levels: architectural and territorial.

The first step is to study the concept of campus. My first hypothesis is that the campus concept could generate knowledge about the nature of the relationship between both designs: organizational and spatial. The literature about 
the campus, mostly in the urban sociology field (Hottin, 2004; Genestier, 2002) or in urbanism (Merlin, 1995), takes interest in the campus as an object. It discusses the link between the city and the university or the effects of campus development but does not discuss the campus as a concept. By contrast, the literature on the history of campus architecture provides examples of former campus conceptions which can be used to question what is included in the notion of campus through design principles. The hypothesis here is that a genealogical approach - based on Michel Foucault's methodology (Foucault, 1975 ) - to the history of campus architecture could reveal some specific properties of this concept through time and through the analysis of the design of current campuses.

In his text Nietzcshe, Genealogy, History (1977), Michel Foucault criticizes the idea of history methodology in "terms of a linear development" and argues that "genealogy retrieves an indispensable restraint; it must record the singularity of events outside of any monotonous finality; it must seek them in the most unpromising places [...] it must be sensitive to their recurrence, not in order to trace the gradual curve of their evolution, but to isolate the different scenes [...] (Foucault, 1977, 140).

Pesqueux and Saudan (1996) present and see a great interest in the use of the genealogy methodology developed by Foucault in Discipline and Punish (1975). However, they do not specify how to use this methodology and refer to its use by English scholars, mainly in the accounting field to analyse, for example, disciplinary power (Hoskin, 1986). French scholars have more recently adopted the methodology in order to analyse collective action with the aim of "shedding light on points of rupture of long history of collective action and artefacts deployed for its management" (de Vaujany, 2011, 3). It seems that the use of a genealogical approach to analyse a concept or a subject through time could reveal different forms of this concept or subject; collective action or disciplinary power for example.

Hence, this chapter's aim is to use a genealogical approach to the history of campus architecture neither for the search for the origins nor for the evolutions of the campus concept but to seek and to isolate different types of campus designs to identify recurrent components of this concept through time. Also, this approach could shed light on differences in the campus components and on the relationship between these components. The hypothesis is that this genealogical approach could generate an analytical framework to explore campus design.

So, this contribution discusses the following research question:

How can a genealogical approach to the history of campus architecture generate knowledge about the relationship between both design principles: organizational and spatial?
In order to investigate this question, the chapter is divided into three sections.

The first section investigates five examples of campus conceptions from the 19 th century to the 1960s. The second section implements the genealogical approach of the campus in order to identify the recurrences, the differences, and the relationships between the components of the campus. This section presents the campus as a scalable concept through time, the essence of which is to organize collective life. It also reveals the consistency of the relationship between organizational design and spatial design principles.

Finally, the genealogical approach generates a framework which is used as a tool to analyse the relationship between the design processes through the example of the Campus Paris-Saclay project.

\section{Campus design history}

This section focuses on five examples of campus conceptions from the early

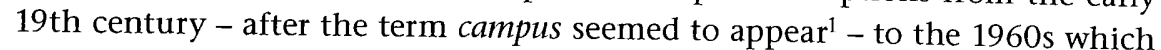
was a period of campus development worldwide. The choice to isolate these examples is relevant because they illustrate the creation of new types of institutions related to several reforms of the higher education system in the United States and in Europe.

The study focuses, firstly, on two examples of campus conceptions as an ideal place: the new university through the concept of the academic village and the democratization of the higher education system through the concept of the university community during the 19th century. It analyses, secondly, the campus conception for the modern university with the development of the research function through the concept of a recognizable university architecture at the beginning of the 20th century. Finally, it considers two different approaches to campus conception for the mass university during the 1960s: the functionalist approach proposes a theorization of campus spatial design and the sociological approach proposes to organize spatially a relationship between several communities (teaching and research).

\section{The ideal place}

From monastery spatial organization to campus specificities: the conception of an ideal place

According to Paul Venable Turner, "the word campus, more than any other term, sums up the unique physical character of the American college and university [...] But beyond these purely physical meanings, the word has taken on other connotations, suggesting the pervasive spirit of a school, or its genius loci, as embodied in its architecture and grounds" (Turner, $1984,4)$. 
Turner (1984), a professor of architecture history at Stanford University in California, produced a formal and thematic typology of American campuses through a historical study of their conceptions in his book Campus: An American Planning Tradition. His study is based on a wide archives analysis. The colonial period (1492-1775) is symbolized by the establishment of numerous colleges by the Puritan colonists.

According to the author, the American higher educational system was traditionally influenced by the British ideal of a collegiate organization where students and teachers lived and studied together in small educative and social structures - in reference to the monastic life.

The British reference to spatial organization was the quadrangle formed by several buildings situated downtown. The buildings included primary structures such as a chapel, a hall - used for the meals, lessons and all assemblies - the students' rooms and a building dedicated to the management of the institution. These several architectural elements set up in a quadrangle shaped an internal closed courtyard used as a meeting place. It also was used as a distribution system to the various buildings. In 1671, Harvard founders "were resolute in the collegiate belief that higher education is fully effective only when the students eat, sleep, study, worship and play together in a tight community" (Turner, 1984, 23).

Hence, according to Turner's research, the organization of the student's life became a major issue and a specificity of the campus concept. This concept enhances and integrates the organization of activities relating to the academic programs. Thus, teaching buildings are composed of teaching and study spaces as well as living spaces - dormitories and dining halls.

After the American Revolution (1775-1783) and the creation of the United States, numerous new higher education establishments were created. About the conception of these new institutions during the 19th century, Turner notes that the campus as a "microcosm, has been shaped by the desire to create an ideal community [...]. Above all, the campus reveals the power that a physical environment can possess as the embodiment of an institution's character" (Turner, 1984, 305).

\section{The academic village}

After the creation of the United States, a higher education system at the national level was organized. Thomas Jefferson, statesman and architect, conceived between 1771 and 1820 the plans for the University of Virginia as a pattern for the new state university. His main principle was to conceive a university like a village. His idea was "to erect a small and separate lodge for each separate professorship, with only a hall below for his class, and two chambers above for himself; joining these lodges by barracks for some students, opening into a covered way to give a communication between the schools. All of these being arranged around an open squation between all and trees which would make it, what it should be Village" (Turner 1984,79). For the fact, an Academic "best health, proposes a social and functionality conditions." ${ }^{2}$ The formal description domestic and educative spaces.

\section{The university community}

The purpose of the "democratic college" through "the Land Grand College Act" voted in by the American Congress in 1862 was to democratize and generalize the higher education system by the development of new programs such as agriculture and sciences. Therefore, many new colleges were created during the second half of the 19th century. Frederick Law Olmsted, an American landscape architect, journalist, and public administrator, "created a type of campus that reflected the new democratic impulses in education" (Turner, 1984, 129). He exposed his concept in a report ${ }^{3}$ he was asked to write by the trustees of the College of California - later Berkeley - to study the future site of their college. His idea was that the college community had to be part of a wider community and, therefore, he proposed to design a beneficial environment for students. The ideal place, according to him, was "neither in the country divorced from "domestic life" and "civilization", and producing "the barrenness of monastic study", nor in the midst of a city, with its distractions. The proper location was a planned suburb, of the sort that Berkeley, close to Oakland and San Francisco, could become" (Olmsted 1997, 265).

Olmsted's concept was to create the physical conditions in the middle of the nature to welcome a community composed of farmer's families, students, and teachers - for a healthy way of life. He also recommended the development of many services, such as doctors, nurses, and craftsmen. The main innovation of Olmsted's project is his idea to integrate the student community in its environment by establishing their housing as part of the wide community.

The 19th century idea of designing a campus as a village or as a planned suburb evolved into, at the beginning of the 20th century, the idea of designing it as a town. The architect, Le Corbusier, as he visited some American campuses in 1935, considered the university installations as "paradise" and as "urban unity, [...] a city, small or large. But a green city" (Le Corbusier, 1937, 155). 


\section{A particular university architecture? The modern university}

According to Turner, in the early 20th century, the American higher education system was influenced by Wilhelm von Humboldt's vision of the ideal university. Humboldt developed the concept of Berlin University in the early 19th century characterized by the unity of teaching and research (von Humboldt, 1903-1936) through the formation of many specialized faculties. Hence, the modern American university became a combination of the German concept and the American tradition of colleges, with a main new function: research.

In the same period, literature about campus planning appeared in the United States. The doctrine defended the development of a particular university architecture. For example, the architect and educator, Alfred D. F Hamlin, recommended in his article "Recent American College architecture" (Hamlin, 1903) to use the master plan as a planning tool, in order to create a general "effect of unity". The master plan allows, indeed, conceiving of a uniformed structure of several buildings. According to Hamlin, a good master plan was especially important, because of the complexity of the modern university, which, in contrast to the two or three simple buildings adequate for an earlier college, now required libraries, laboratories, lecture halls, gymnasia, administration buildings, dining halls, and clubhouses (Hamlin, 1903).

In 1906-1907, the architect Alfred M. Githens published a succession of articles on "group plans", or the design of ensembles of buildings in Brickbuilder (Githens, 1907). Githens presented a classically Beaux-Arts analysis by dividing plans into categories based on their overall shapes - such as the "closed court", the "open court", the "line", the "avenue", and the "unsymmetrical composition on two axes" (Githens, 1907). All these architectural elements belong to urban grammar. For Githens, the campus was an essential part of American tradition, the "natural center to group the teachings" (Githens, 1907), and its architecture had to be recognizable.

After the Second World War, the university development reached a new level with an important democratization movement and the creation of new institutions. Hence, the "mass university", with an increasing number of students and functions, changes the planning programs for new campuses; they became more complex.

\section{A possible theorization of campus design? The mass university}

\section{The functionalist approach}

One consequence of the complexity of the mass university was the adoption of the modern architectural theory developed in the first half of the 20th century by Walter Gropius in Germany and Le Corbusier in France, especially. approach. According to Gropius, "a standard standardization and a functional practical exemplar of anything in the best of its anterior forms - a fusion pre which embodies a fusion of personal content of their designers and all otherwed by the elimination of the features. Such an impersonal standard is callerwise ungeneric or nonessential a carpenter's square" (Gropius, 1965, 34). Called a "norm", a word derived from Le Corbusier proposed the "keys to tow functions: housing, work, recreation (during leisure), and traffic (Le Corbusier, 1973, 77).

Richard Dober, architect and consultant, transposed these principles without its social meaning, according to Muthesius - to the campus planning which which can be applied generally; a proposition for standardization of the spatial organization of campus. The functions of a campus defined by Dober are the library, the museum, the laboratories, the teaching spaces, the social spaces, the administration, the housing, the sportive and recreational activities, the distribution system, and the parking. For Dober, the most importanties, the campus design is to the most important step for "planned design is to translate the needs in various functions, in surface and in "mino" and ines". For Dober, the streets should be divided into "major" and "minor", and the campus, as an entity, should be surrounded by a ring road
(Dober, 1963).

According to Dober, once each module is identified, it is possible to imagine "the module like a chess and the campus as a chessboard" (Dober, 1963, 61).

In his book ${ }^{4}$ The Postwar University: Utopianist Campus and College, published in 2000, Stefan Muthesius, a specialist in 18th to 20th century's history of architecture, insists on the idea that university design has become an "organizational and technical process" in the 1960s (Muthesius, 2000, 25). Dobers's approach was one answer to the increasing complexity of the mass university, but some other answers were proposed.

\section{The sociological approach: Reformuniversität of Konstanz}

One of the characteristics of the mass university was to group several communities - departments for example - in the same place. According to Muthesius, campus designers borrowed the sociological methodology of socio-diagrams based on network analysis (Muthesius, 2000, 89) in order to represent the relationship between departments and the possible interdisciplinarity in university daily life. These design processes of social organization were used in the United States, the United Kingdom, and Germany in the 1960s where new campuses were developed. 
The Reformuniversität of Konstanz in Germany, which was requested by the Land in 1965, is a relevant example. The project aim was, according to Muthesius, to "express through the building the determination of mixing the academic research and the teaching" (Muthesius, 2000, 237). The classroom design process "took three years, helped by many socio-diagrams", and one of the designers insisted on the fact that "the relationship between knowledge and its physical incarnation is neither innocent, nor accidental" during the conception processes. "The Oxford quadrangle allowed calm and intense contacts between the members of the community at the same time" (Muthesius, 2000, 237). The main specificity of this example is the way the workspaces and the circulation systems are punctuated by rest spots. These spaces were designed to allow "spontaneous" meetings (Muthesius, 2000, 239).

Although the analysed sources are not structured on the same approach archives analysis and comparative study - an examination of the narratives of these five examples from the history of campus architecture identifies and isolates recurrent components of the campus through a genealogical approach.

\section{A genealogical approach of campus designs}

I have identified seven recurrent components in the five campus types which are the physical characteristics - spatial organizations and geographical implementations - the context of the higher educational system, organizational design principles (academic and research), spatial design principles, functions, main actors, and the choice of planning tools.

The intent in the second section is to use the identified components in order to establish an analytical framework. The aim of this framework is to compare the five campus types in order to shed light on the recurrences and differences and to understand potential relationships between the components.

\section{Recurrences}

The five types of campuses present four constant components through time (Figure 10.1). A campus conception always seems to be related to the social aim of establishing or reorganizing a community. This organizational principle is related to a specific spatial organization referring to the village or the town. The establishment of the campus outside the city - referring to an American planning tradition according to Turner - as a unit independent set. The university community developed by Olmsted in the 19th century is a remarkable example of the campus integration in the suburb community. This specific location explains how the American campus is traditionally conceived of as a small town with a strong social life, such as through fraternities and clubs, and

\section{Organizational design principles}

Establishing or
reorganising a community

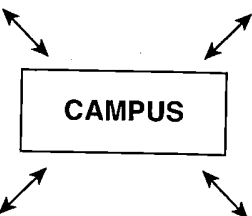

\begin{tabular}{l} 
Stable base \\
- teaching \\
- studying \\
- eating \\
- sleeping \\
\hline
\end{tabular}

Characteristics

Independent

set/uniformed

structure

Outside the city

Figure 10.1 The constants of the notion of campus

Source: Author's own.

with services and public spaces. Teaching, studying, eating, and sleeping are, according to the history of architecture literature, the stable basic functions a campus is made of.

\section{Differences}

The establishment of the analytical framework can be used in order to shed light on the differences of the campus concept through time.

This framework allows comparing the five examples vertically (Table 10.1) in order to identify differences between them over time in relation to the seven components. Thus, an increase in the number of functions over time can be noticed as well as the different choices of planning tools. There is an absence of higher education actors in the 1960 functionalist approach. This absence can be explained by the theory developed by Dober which was, according to Muthesius, highly criticized by other architects because it did not pay attention to organizational academic issues and was focalized in architectural matters. For Muthesius, Dobers's concerns were the practical functions of the institution while the relationship between social stakes, educational programs, and spatial design issues seemed not to be developed in his theoretical attempt. (Muthesius, 2000, 28).

Regarding the organizational design principles, a transformation from the establishment of a community in an ideal place - the academic village - to the concept of mixing several communities in the same place - Reformuniversität 
in Germany - shed light on a demographic issue of the notion of campus. According to the literature (Turner, 1984; Muthesius, 2000), the first campuses were designed to host small communities and, over time, vast communities.

The variables show the unstable nature of the notion of campus and its scalable property.

\section{Relationship between the components}

An analysis of the framework horizontally may be useful in order to explore possible relationships between the components of a campus design type. Although this study does not pretend to show determined relationships, the aim is to try to present some recurrent consistencies through the relationship between organizational and spatial design principles.

The analysis of the relationship between the principles reveals that the priority of the first campus designers was to conceive specific spatial organizations to build and host a community. In fact, regarding the example of the academic village, organizational design principles and spatial design principles seem to interact. Hence, Jefferson and Olmsted, as both statesman and architect, conceived at the same time an organization and its physical incarnation. Jefferson and Olmsted designed the organization of the new state university through a spatial perspective.

Since the 1960s and the massive university development, the aim has been to group several communities - colleges, departments, etc., and create a social link between them - materialized by specific architectural elements, especially the distribution systems: quadrangle, galleries, public places, etc. Hence, the design principles could be related to the functions and the choice of the planning tools.

The Reformuniversität development of the mass university in Germany is related to the organizational design principles of mixing several types of communities: teaching and research. This organizational design principle is consistent with the spatial design principle of organizing the relationship between the communities. These principles are consistent with the meaning of the distribution systems and meeting places in the spatial organization. In addition, the choice of the socio-diagrams as a planning tool is consistent with the principles of mixing several communities and the idea of organizing spatially the relationship between these communities.

The question of the choice of the planning tool refers to architectural practices. For example, the master plan was used for the modern university example at the beginning of the 20th century in order to give the campus a uniform structure and to reflect the concept of unity. Later, in the 1960s, the functionalist approach developed by Dober used the master plan in order to respond to the spatial design principle of standardization. 
According to the genealogical approach, it appears that the master plan has been used to conceive the campus as one coherent piece and the more the number of functions increased, the more efficient it seemed.

The consistency between organizational design principles and spatial design principles are recurrent in all the examples studied, except for the functionalist approach developed by Dober where organizational design principles and spatial design principles seem to be parallel. This consistency is the result of either the practices of actors - Jefferson and Olmsted - or is provided in the design of campus design programs as in Konstanz because the aim was to "express through the building the determination of mixing the academic research and the teaching" (Muthesius, 2000, 237).

The genealogical approach reveals three main results. Firstly, the essence of the campus is to organize the collective life of students and scholars with specific architectural elements and a recurrent reference to village, suburb, or town. Thus, campus conception could be placed in a town planning tradition, considering, according to Lewis Mumford, the "fundamental function of the city consists to give a collective form, in order to allow contact and cooperation of many individuals. [...] This organization must favour numerous meetings, competitions between individuals and diversify groups" (quoted in Choay, 1965, 365).

Secondly, it also shows the campus as a scalable concept trough time. Hence, the campus is not a stable concept; it is linked to contextual and demographical factors. Although the campus is not a stable concept, it appears that it is recurrent over several centuries and in different countries as an answer to higher educational system changes.

Finally, the genealogical approach the nature of the relationship between organizational design and spatial design principles through the recurrence of the consistency (Figure 10.2).

The illustration of the consistency between organizational design and spatial design principles shows the role of this consistency during the design processes. How do both design principles interact with each other?

The history of campus architecture is not able to analyse at the micro-level the design processes of campus conceptions, but the examples of the academic village, the university community, and Konstanz has shown a powerful

\begin{tabular}{|c|c|}
\hline Organizational design principle & Spatial design principle \\
\hline
\end{tabular}

Figure 10.2 Illustrates the consistency between organizational design principle and spatial design principle

Source: Author's own. interaction and unity between the conception of an organization and its physical incarnation.

The aim of the last section is to test the hypothesis that the framework generated by the genealogical approach can be used as an analytic tool to explore
the Campus Paris-Saclay project processes.

\section{The framework generated by the genealogical approach: an
analytical tool?}

The concept of campus emerged in the United States and channelled into Europe in the 1960s, as previously observed with the example of Konstanz. The hypothesis in the last section is to use the established framework as an analytical tool in order to explore the design processes of the Campus ParisSaclay project. But, first I review the literature about French campuses built in the 1960s with a view to highlight a potential French tradition.

So, the hypothesis is that this exercise will allow to identify the different components of the Campus Paris-Saclay project and to analyse them through the notion of consistency between organizational design and spatial design principles revealed genealogical approach.

\section{The campus in France: what specificity?}

In France in the 1960s, the American campus had become a reference for public administrators and architects, although the French tradition for the academic institution was to be in the city (Merlin, 1995; Genestier, 2002). A visit to the United States had indeed become a convention for the architects in charge of planning projects. For example, Louis Armand who was in charge of the new implementation of L'Ecole Polytechnique went to the United States to visit campuses to understand the functioning of the social relationships (Hottin, 2004).

As Musselin has analysed in La longue Marche des Universités, the main university organizational principles in France in the 1960s were equality and standardization (Musselin, 2001). According to her, the idea of equality was to pursue the ideal to have the same offerings with the same quality in all French universities at a time of mass university development.

In his book L'Urbanisme Universitaire à l'Etranger et en France (1995), Pierre Merlin studies the state of university urbanism in the mid-1990s in France, Europe, and the United States. His analysis does not identify precisely the spatial design principles, but he describes the realization mechanisms of French campuses. According to Merlin, the questions in France at that time were more technical questions than ideological and, "both planning and realization were extremely centralized. The funding were almost exclusively public. The scholars 
gave their demands to the minister through education officers, ${ }^{5}$ who selected the parcel of land for the construction ${ }^{6}$ and supervised the design of master plans" (Merlin, 1995, 263). The author insists on a specific centralization of decisions in a rigid legal context, where classroom sizes, buildings, and costs were designed on pre-established standards. According to Merlin, the realizations in the 1960s were highly criticized, especially because of the incapacity to design "a real neighbourhood [...] with services, traditional urban shapes as the street, the place, etc" (Merlin, 1995, 264).

Hence, the French campus design is based, at that time, on a rational spatial organization by the juxtaposition of functions, which was the design methodology established by Dober in the United States at the same time. This rational organization is not inconsistent with the organizational design principles of equality and standardization highlighted by Musselin, but they seem not to be related to each other, since scholars were not directly involved in the conception processes, according to Merlin. Organizational design principles and spatial design principles seem to be independent from each other.

As a result, the examples of campuses developed in France in the 1960s reveal French mechanisms of realization. The equality and standardization principles are not about the construction of the collective life, which shows a major rupture with the first campuses analysed.

Therefore, the aim is to explore, through the same framework, the organization of the current Campus Paris-Saclay project in order to highlight possible continuity or rupture in the conception processes through time.

\section{The Campus Paris-Saclay conception processes: between continuity and rupture?}

The Campus Paris-Saclay project is based on two documents: the "Plan-Campus du plateau de Saclay" (2009) which reports about the real estate projects of the institutions involved in the project, and the "Submission form IDEX ParisSaclay" (2012) which reports on the organizational project for the new university and the scientific project (academic and research).

The project is part of the implementation of a nationwide public policy regarding France's higher education and research system as well as a territorial project which aims to organize a scientific cluster. Thus, this project can be placed in several schools of thoughts relating to organization and the generation of knowledge through, on the one hand, the collaboration between the academic and the private world (Gibbons, 1994), and on the other hand, an approach based on the triple helix metaphor which represents the relationship between the university of science, private organization, and public administration (Etzkowitz \& Leydesdorff, 2000). In addition, the model of cluster described by Porter (1998) in the late 1990s and its geographical proximity dimension appears to be a strong reference for the Campus Paris-Saclay
project.

The campus project started in 2008 and is implemented through two governmental financial programs: "Investments for the future Program" to finance the scientific programs and "Campus Plan" for the real estate projects. This project is a case of organizational design with the creation of the University Paris-Saclay (UPS) as well as a case of spatial design with the real estate project and the new territorial organization through the development of the projects

The foundation of scientific cooperation (FCS) - composed by scholars, mainly directors of institutions - is in charge of the conception of the academic and scientific project involving over 20 actors in order to create a new institution and the Paris-Saclay Public establishment (EPPS) - composed mainly by project managers - is in charge of the space organization at two levels: architectural and territorial.

Hence, from an institutional point of view, the organizational design and the spatial design processes are separate and managed by different entities. The spatial design process began in 2008 and the organization design process in 2010. This order contradicts the traditional sequential structure presented by Vaaland $(2010,10)$ where organizational design process precedes the architectural design process.

An analysis of the document "Submission form IDEX Paris-Saclay" (2012) reveals the concept of cooperation between several communities (education, research, economic world) as the main organizational design principle at Saclay. In the "Plan-Campus du plateau de Saclay" (2009), two spatial design principles appears; firstly, the concept of proximity by grouping the buildings of institutions involved in the project and, secondly, the necessity to have common buildings. Moreover, this plan presents the real estate project for the campus through a conception institution by institution on the same realisation mechanisms Merlin described for the French campus design in the 1960s.

Based on these organizational and spatial elements, I propose to deconstruct the French Campus design from the 1960 and the Campus Paris-Sacaly project by using the analytical framework generate by the genealogical approach.

By using the analytical framework established above (Table 10.2), the aim is to isolate the different components of the Campus Paris-Saclay project in order to, firstly, compare them vertically to the components of the French campus example conceived in the 1960s and, secondly, to test the relationship - horizontally - of consistency between organizational design and spatial design principles.

The Campus Paris-Saclay project is interesting in its ambivalent structure. On the one hand, the organizational design principles (research and academic) of cooperation show a strong determination to organize the collective life of the new university of a new community, in rupture with the French higher 
education system established on equality and standardization and, on the other hand, the current spatial organization shows a continuity with the spatial mechanisms. At the same revalional institutions mechanisms. At the same time the principle of common buildings emerge as a spatial design principle. The stake of the empirical study at a micro-level is to question how these principles are translated into processes and how the organizational design principle of cooperation acts on the spatial design principles

Vaaland (2010) proposes to consider end-user participation as a way to study the link between the processes, but the Campus Paris-Saclay could be a "laboratory" at different level: architectural and territorial.

The common building projects seem to be a relevant way to study the nature of the relationship between organizational design and spatial design processes at Saclay. These projects could be a way to identify a disruption to the rational realization mechanisms or of the structure of the project management. They may generate new organizational design principles, functions, and planning tools for example.

The research for common building projects at Saclay revealed the conception of the Learning Centre, which was not planned in both organizational and spatial programs. It emerged during the project design processes and is not predefined. This case study raises the question to design the organization of cooperation between several institutions and the spatial organization at the same time. The functions of the future building need to be invented as well as the planning tool for its realization. Hence, both managements - scientific and spatial - are interested in the project. The scientific management seeks the materialization of the cooperation on the campus, and the space management needs a symbolic building on the campus.

At the territorial level, the analysis of the analytical framework sheds light on a filiation between the spatial organization at Saclay characterized by an open set linked to its social, geographical, and economic environment and the type of campus developed by Olmsted in the 19th century. These spatial organizations show a rupture with the "independent set" recurrent physical characteristics of the other types of campuses. This filiation allows interrogating the relationship between the organization of the scientific community and the rest of the environment - for example agriculture, which is a traditional activity of the Saclay territory - and the spatial organization of the territory.

Hence, the design processes are not totally separate, and the aim of an empirical study is to identify how and where the link is generated through structures and/or actors.

\section{Conclusion}

This chapter shows that the essence of the campus is to organize the collective life of students and scholars. It also reveals that the campus is not a stable 
concept and that the design principles of this object show a strong interaction between organizational design and spatial design. Although the campus is not a stable concept, it appears that it is recurrent over several centuries and in different countries as a solution to spatially organized higher educational institutions.

Through the study of the concept of campus through time, this contribution demonstrates that the separation between organizational design and spatial design described by Vaaland (2010) was not always true and that this separation may be related to specific organizational design and spatial design practices. Hence, this chapter shows how a genealogical approach of history can contribute to the analysis of these practices through the design processes of a new campus.

From a methodological point of view, this chapter shows the capacity of architecture history to provide information about organizational design principles as well as organizational spatial principles. The genealogical approach allows the identification of recurrent components of a notion, and it can generate an analytical framework in order to analyse the relationship between organizational design and spatial design processes. The nature of this relationship is a way to explore both spatial design and organizational design practices - actors, design tools, etc. Thus, this methodology allows analysing design processes through a particular point of view, and moreover, this framework could be used to trace the projects' evolutions - new principles, new planning tools, new actors, etc., during the design processes.

\section{Notes}

1. According to the author, the word appeared in the late 18 th century at the New Jersey College, later Princeton College.

2. Letter from Jefferson to Hugh L. White et al., Trustees of the Lottery of East Tennessee College, May 1810.

3. F. L. Olmsted (1997), "Report upon a Projected Improvement of the College of California, Near Oakland", 1866, In Civilizing American Cities; Writings on City Landscapes, pp. 265-291.

4. A comparative study of international campus development during twenty years after Second World War.

5. Le recteur d'Académie.

6. Usually outside the city where land was available and at a competitive price.

\section{References}

Choay, F. (1965). L'Urbanisme, Utopies et Réalités. Paris: Editions du Seuil.

Clegg, S., \& Kornberger, M. (2006). Space, Organizations and Management Theory. Oslo and Copenhagen: Liber and Copenhagen Business School Press. de Vaujany F.-X. (2011). A new perspective on the genealogy of collective action through the history of religious organisations. Management and Organizationa through $65-78$

de Vaujany, F.-X., \& Vaast, E. (2013). If these walls could talk: the mutuat constuction

organizational space and legitimacy, Organization Science, the mutual construction of Dober, R. (1963). Campus Planning New York: Reinhold. September, 1-9.

Duby, J.-J. (1999). Propositions pour le Plateau de Saclay. rapport remis à Claude Allègre. Elsbach, K. D., \& Pratt, M. G. (2007). 4 The Physical Environment in Organizations. The
Academy of Management Annals, 1(1), 181-224.

Etzkowitz, H., \& Leydesdorff, L. (2000). The dynamics of innovation: from National Research Policy, 29, 109-123.$$
\text { Research Policy, 29, 109-123. }
$$

Foucault, M. (1977) [1975]. Discipline and Punish. New York: Pantheon Books.

Foucault, M. (1977) [1971]. Nietzsche, genealogy, history. In M. Foucault, \& D. F. Bouchard (eds) Language, Counter-Memory, Practice: Selected Essays and Interviews, Ithaca: Cornell University Press, pp. 139-164.

Genestier, P. (2002). L'université et la cité. Espaces et sociétés, 80-81, 21-41.

Gibbons, M., Limoges, C., Nowotny, H., Schwartzman, S., Scott, P., \& Trow, M. (1994) The New Production of Knowledge: The Dynamics of Science and Research in Contemporary Societies. London: Sage.

Githens, A. M. (1907). Universities, colleges and schools. The Brickbuilder, article V, December.

Gropius W. (1965) [1935]. The New Architecture and the Bauhaus. Cambridge, Ma.: MIT Press.

Hamlin, A. D. F. (1903). Recent American college architecture. The Outlook, 1 August, 790-799.

Hernes, T. (2004). The Spatial Construction of Organization. Amsterdam, Philadelphia: John Benjamin Publishing Company.

Hoskin, K., \& Macue, R. (1986). Accounting and examination: a genealogy of disciplinary power, Accounting Organisations and Society, 11(2), 105-136.

Hottin, C. (2004). Les Délices du campus ou le douloureux exil. Trois grandes écoles parisiennes face à leur transfert (1950-1980). Histoire de l'Education, 102, 267-293.

Humboldt, W. von (1903-1936). Gesammelte Schriften. Ausgabe der Preubischen Akademie der Wissenschaften. Werke [Oeuvres choisies: Edition de l'Académie des Sciences de Prusse], Berlin, 17.

Le Corbusier (1973) [1933]. The Athens Charter. New York: Grossman Publishers.

Le Corbusier (1937). Quand les Cathédrales Etaient Blanches: Voyage au Pays des Timides. Paris: Plon.

Plan-Campus du plateau de Saclay (2009). Rapport, Tomes 1 et 2.

Merlin, P. (1995). Urbanisme Universitaire à l'Etranger et en France. Paris: Presses de l'Ecole Nationale des Ponts et Chaussées.

Musselin, C. (2001). La Longue Marche des Universités Françaises. Paris: Presses Universitaires de France (Sciences Sociales et Sociétés).

Muthesius, S. (2000). The Postwar University. Utopianist Campus and College. New Haven and London: Yale University Press.

Olmsted, F. L. (1997) Civilizing American Cities: Writings on City Landscapes. Cambridge, Ma.: Da Capo Press.

Pesqueux, Y., \& Saudan, A. (1996). Foucault et la méthode généalogique: à propos de "surveiller et punir". Comptabilité et Développement, 1041-1055. 
Porter, M. (1998). Clusters and the new economics of competition. Harvard Business Review, November-December, 77-90.

IDEX Paris-Saclay (2012). Submission Form.

Taylor, S., \& Spicer, A. (2007). Time for space: a narrative review of research on organizational spaces. International Journal of Management Review, 9(4), 325-346.

Turner, P. V. (1984). Campus: An American Planning Tradition. Cambridge, London, New-York: M.I.T Press and the Architectural History Foundation.

Vaaland, M. (2010). What we Talk about when we Talk about Space: End User Participation between Processes of Organizational and Architectural Design, PhD dissertation. Department of Organization, Copenhagen Business School. http://openarchive.cbs. dk/bitstream/handle/10398/8002/Marianne_Stang_Vaaland.pdf?sequence=1

Van Marrewijk, A., \& Yanow, D. (2010). Organizational Spaces, Rematerializing the Workaday World. Northampton: Edward Elgar.

Yoo, Y., Boland, R., \& Lyytinen, K. (2006). From organization design to organization designing. Organization Science, 17(2), March-April, 215-229

\section{Conclusion: Understanding Materiality and the Material Underpinnings of Organizations through a Longue Durée Approach} Nathalie Mitev, Francois-Xavier de Vaujany, Emmanuelle Vaast and
Pierre Laniray

Throughout this book, our contributors have proposed several important concepts to make sense of the materiality and the material dynamics in organizations and organizing: standards and standardization processes (JoAnne Yates, Nadine Arnold), affordance (Emilie Bérard), iconography (FrancoisXavier de Vaujany and Emmanuelle Vaast), presentism and historical regimes (François Hartog, Nathalie Mitev), morphology (Caroline Scotto), material traces (Christine McLean, Jeremy Aroles, Zsuzsanna Vargha), reputation crisis (Hélène Lambrix), and time-and-history regimes (Peter Clark).

Most contributions went beyond short-term observations in their organizational analysis and emphasized the importance of longue durée as a process and a product of the past. In order to grasp the symbolic and material aspects of organizations and organizing, the exploration of the various layers of artefacts and practices over time, the development of historical narratives about organizational dynamics and the involvement of organizational members, the identification of successive institutional environments help researchers to come closer to the history of collective entities and collective action. Drawing on Le Goff (2014), a joint analysis of the key "periods" of these broader collectivities and those of the intra-communities and actions inside organizations can be especially illuminating for organizational research. Time dynamics and periods between broad institutional environments, collective entities, and organizations relate and overlap.

History matters, both as an object and a perspective on organizations. Adopting an historical turn in research on sociomateriality (Orlikowski, 2007; Leonardi, 2011), material processes (Carlile et al., 2013), or organizational space (Clegg \& Kornberger, 2006) could be very fruitful. It could result in the 